\title{
Explaining trends of premarital childbearing among young women in Uganda
}

\author{
Natal Ayiga \\ Population Research and Training Unit, North West University-Makikeng \\ Campus, Private Bag X2046, Mmabatho 2735, South Africa. Email: \\ Natal.Ayiga@nwu.ac.za; naviga1962@gmail.com
}

\begin{abstract}
Young motherhood is associated with persistently high rates of fertility and adverse maternal, neonatal and social outcomes in many sub-Saharan African countries. This study examined the trends and explained the persistence of high incidence of premarital childbearing among sexually active unmarried women in Uganda. Cross-sectional data from the 200I, 2006 and 201I Uganda Demographic and Health Surveys were used. The study revealed that across the span of the study period the prevalence of premarital childbearing remained high and stable at more than $25 \%$ in all the three surveys. Premarital childbearing is significantly predicted by age group 20-24, young age at sexual debut, female headed households, and households headed by the young women themselves, low level of education, rural residence and multiple lifetime sexual partnerships. Increasing and maintaining access to programmes that increase age at sexual debut, level of education and reduce number of lifetime sex partners are recommended.
\end{abstract}

Keywords: Premarital pregnancy, premarital sex, unmarried women, young motherhood

\section{Résumé}

La maternité précoce ou juvénile est associée à la persistance de taux élevés de fécondité et maternelle défavorable, les résultats néonatals et sociaux dans de nombreux pays d'Afrique sub-saharienne. Cette étude a examiné les tendances et a expliqué la persistance de la forte incidence des grossesses avant le mariage chez les femmes célibataires sexuellement actives en Ouganda. Les données transversales de l'Enquête Démographique et de Santé de l'Ouganda 200I, 2006 et $20 \mathrm{II}$ ont été utilisées. L'étude a révélé que sur toute la durée de la période d'étude, la prévalence de la fécondité prénuptiale est resté élevé et stable à plus de $25 \%$ dans les trois enquêtes. La fécondité prénuptiale est considérablement prédite par groupe d'âge 20-24, le jeune âge au premier rapport sexuel, les 
ménages dirigés par des femmes, et les ménages dirigés par les femmes ellesmêmes, les jeunes à faible niveau d'éducation, la résidence rurale et de multiples partenariats sexuels à vie. Augmenter et maintenir l'accès aux programmes qui augmentent l'âge au premier rapport sexuel, niveau d'éducation et de réduire le nombre de partenaires sexuels à vie est recommandée

Mots-clés: la grossesse avant le mariage, le sexe avant le mariage, les femmes célibataires, les jeunes de la maternité

\section{Introduction}

Premarital childbearing by young women aged I5-24 years, which is associated with adverse maternal, neonatal and social outcomes, remains a major problem in low resource countries, particularly in subSaharan Africa (Najati \& Gojazadeh, 20l0). The HIV/AIDS disease, which is predominantly sexually transmitted and widespread among young unmarried women, has highlighted the urgency of addressing this problem (Christofides, Jewkes, Dundle, Nduna, Shai \& Sterl, 20I4), particularly in countries where HIV is now a large pandemic (UNICEF, 20I I).

Most of the research evidence from sub-Saharan Africa has identified HIV infection (Aderbigbe et al., 20II); unsafe abortion due to unwanted pregnancies (Raj, Saggurti, Bilaiah, \& Silverman, 2009); maternal morbidity and mortality (Chirowa, Atwood \& Van der Putten., 20I3); and increased risk of infant mortality (Samandari \& Speizer, 20l0) as some of the adverse health outcomes of young motherhood. Additionally, the disruption of education through school dropout (Karabo \& Ayiga, 2014; Steel, SigleRushton \& Kravdal, 2009); higher rates of poverty for the children of young unmarried women (Behrman, Murphy,
Quisumbing \& Yount, 20I0) have also been identified as adverse social effects of young motherhood.

Uganda with $25 \%$ has one of the highest prevalence of premarital childbearing among women aged 15-24 years in sub-Saharan Africa (Uganda Bureau of Statistics [UBOS] \& ICF Inc, 20I2), which has contributed to the country's high and stagnating maternal mortality ratio of 438 and neonatal mortality rate of $27 \%$ (Ministry of Health, 2013). It has also contributed to the high school dropout rate among girls and poverty among young unmarried mothers in Uganda (Sekiwunga \& Whyte, 2009). This high premarital childbearing is occurring in the backdrop of the considerable socioeconomic and cultural transformations the country achieved in the last two decades. Therefore what explains the persistent high premarital childbearing in Uganda? The objectives of this study are therefore to examine the trend and identify the predictors of the continued high premarital childbearing among young women in Uganda.

\section{Literature review}

A number of studies have suggested that the prevalence of premarital childbearing is 
increasing in sub-Saharan African countries (Richter, 2010; Temin \& Levine, 2009; Meekers, 1994). Poverty, sex for financial and material gain (UNFPA, 20I0) changes in cultural sexual norms and the failure of the African family structure in providing support for young women as they transit through childhood to adulthood are factors contributing to the increasing rate of premarital childbearing in many of these countries (Sekiwunga \& Whyte, 2009; Mensch, Grant, Blanc, 2006). Other factors predicting premarital childbearing identified by previous studies include the declining age at puberty which is characterized by biological, psychological and emotional changes leading to young age at sexual debut and sexual risk taking by young women including crossgenerational sex (having sex with much older men) (Wegner, 2008); engaging in multiple sexual partnerships; a high turnover rate of sexual partners (Gupta \& Mahy, 2005); young age at first pregnancy and childbirth (Sommer, 201 I; Bogale \& Seme, 2014); high school dropout and limited education (Marston et al., 2013). Living in rural areas (UNFPA, 20I0); living in a dysfunctional family; living in single mother headed families (Högnäs \& Carlson, 2012; Amato, 2005); and absence of fathers for extended periods (Ellis, Bates, Dodge, Fergusson, Horwood, Pettit \& Woodward, 2003) have also been associated with premarital young motherhood. Inadequate knowledge and poor access to reproductive health services, especially availability of and access to contraceptives have also been identified as some of the predictors of the persistent premarital young motherhood in sub-
Saharan Africa (Kennedy, Gray, Azzopardi \& Creati, 20I I).

Uganda's high rate of fertility is partly attributed to young age of premarital motherhood which has implications for the countries' population growth (Nalwadda et al., 2010). By 24 years of age, 7 in 10 women in Uganda have given birth and the Age Specific Fertility Rate (ASFR) for the 15-19 and 20-24 year age groups ranged froml34-176 and 313-332 respectively over the 200I-20ll periods (UBOS \& ICFI, 2012). This high ASFR has been attributed to the young median age at sexual debut estimated at 16.4 years for women and a long duration of premarital sexual activity which expose the women to unintended pregnancies (Slaymaker, Bwanika, Kasamba, Lutalo, Maher \& Todd, 2009).

The high prevalence of unintended pregnancy has been blamed for the similarly high level of abortion among young women which has been identified as one of the factors sustaining the high maternal mortality in Uganda (Singh, Prada, Mirembe \& Kigundu, 2005). Unintended pregnancies is also a likely contributor to the resurgence of HIV infection after the first reduction in HIV prevalence occurred in the 1990s mostly by promoting condom use and reduction in the number of sexual partners, also known as zero grazing (UAC, 20|4).

In addition, the young premarital childbearing results in the high dropout rate at primary and secondary schools (Ayebazibwe, 2013; Sekiwunga \&Whyte, 2009; Okumu, Nakajjo \& Isoke, 2008). The current high prevalence of young premarital childbearing is a serious concern in Uganda because it is a factor contributing 
to the failure of the country in achieving most of the Millennium Development Goals including eradicating extreme poverty and hunger, achieving Universal Primary Education (UPE), promoting gender equality and empowerment of women, reducing childhood mortality, improving maternal health, and sustainably combating HIV/AIDS (UNFPA, 2010; WHO, 2008).

Despite the concern due to the high prevalence of premarital childbearing in Uganda and elsewhere in sub-Saharan Africa, there is little research in this area and consequently predictors remain poorly understood in the context of the rapid socioeconomic and cultural transformations in this region. This study therefore examined trends in young premarital motherhood and identified the predictors of young premarital motherhood in Uganda. Specifically, the study tested the hypotheses that "young motherhood was lower between the 1996-200I period than 2007-20II period" and that "women with multiple lifetime sexual partners are likely to experience premarital childbearing compared to women with only one lifetime sexual partner" even after controlling for the effect of selected socio-demographic factors simultaneously.

\section{Materials and methods \\ Data}

The study used cross-sectional data obtained from the 200I, 2006 and 201I Uganda Demographic and Health Surveys (UDHS). The data collected covered a 15 year period. This is because the DHS collects retrospective data on events that occur in the 5 years preceding the survey date. Accordingly, the reference period for the 200 I survey was 1995-200 I that of 2006 was 2002-2006 and that of 20II was 2007-20II. The data were collected at household level from 2445 I comprising of 7246 in 200I, 853I in 2006 and 8740 in 2011 among women aged 15-49 years. These also include visitor women who spent the preceding night in the selected households (UBOS \& ICF Inc, 200I; 2006; 20I2).

The samples for the three UDHS were derived by use of a two stage cluster sampling design. In the first stage enumeration areas were selected as clusters and in the second stage households were selected. A standard structured DHS questionnaire was used by the Uganda Bureau of Statistics (UBOS) to collect the data after obtaining approval from the Bureau's Internal Ethical Review Board which was established by the Statistics Act of 2006. Informed consent was obtained from each respondent after explaining the objectives of the surveys. All interviews were conducted in private, confidentially and anonymously using a questionnaire translated in the native languages of the study districts. Permission to use the data sets from the three surveys was obtained from UBOS.

\section{Measures}

The dependent variable is premarital childbearing, which was measured as having ever given birth before entering any form of sexual union between a woman and a man. The form of union in this regard includes marriage regardless of type (cultural, legal and religious) and cohabitation. The independent variables 
comprised of demographic, socioeconomic and reproductive health variables associated with the women. The demographic variables included were age of the woman categorized as 15-19 years and 20-24 years; age at sexual debut categorized as $<18$ and 18 years or older; age at first birth categorized as $<16,16$ 19 and 20 years or older; age of head of household categorized as $<25,25-34$ and 35 years or older; sex of head of household; and relationship to head of household categorized as self, parent, other relatives and not related.

The socioeconomic variables included religion which was categorized as Christian, Muslim and other (no religion, traditional, Sheik, Hindi and any other minority groups); level of education categorized as no/primary, secondary and tertiary education; place of residence categorized as urban and rural; and wealth index quintile categorized as poorest/poorer, middle and richer/richest. The reproductive health variables included in the analyses were number of lifetime sexual partners categorized as one, two and three or more; HIV testing status categorized as ever tested for HIV and never tested for HIV; knowledge of contraceptive methods and ever use of contraceptives which were both categorized as yes and no.

\section{Statistical analysis}

Responses were analyzed on 549, 636 and 739 unmarried women who had initiated sexual activity from the 200I, 2006 and 201 I surveys respectively. The first stage of data analysis involved the description of the demographic, socioeconomic and reproductive health profiles of the women.
In the second stage, differentials in young motherhood were analyzed by demographic, socioeconomic and reproductive health variables. The Chisquare statistics was employed to test the hypothesis that "women with multiple life time sexual partners are more likely to experience premarital childbearing compared to women who have only one lifetime sexual partners" The above hypothesis was tested at the $95 \%$ Confidence Interval.

In the third stage, the adjusted logistic regression model was used to test not only whether or not the hypothesis was confirmed, but also assess the changes in predictor variables and their effects on young premarital childbearing over the three surveys by using the changes in Odds Ratios (OR) and the $p$ values. The logistic regression model was chosen because the outcome variable was binary and coded "I" if women reported they had given birth and " 0 " if otherwise, which satisfied the form of data for the use of the binary logistic regression model (Elisa \& Wang, 1992). All variables selected for assessment were included in the multivariate model as all of them contribute to determining the significant predictors of the outcome variable, which in this case is premarital childbearing. The analysis was done by sing SPSS version 22.

\section{Results}

\section{Profile of study population}

Table I presents the socio-demographic profile of the women. The median age of the women was 19 years $(\mathrm{SD}=2.56)$ and the majority (6I.2\%) were $<20$ years of age. The median age of the women at 
sexual debut and first birth were 16 years $(\mathrm{SD}=2.26)$ and 18 years $(\mathrm{SD}=0.9 \mathrm{I})$ respectively and nearly $74 \%$ had sexual debut at $<18$ years of age; nearly $4 \%, 16 \%$ and $7 \%$ had the first birth at $<16,16-19$ and 20-24 years of age respectively. Overall, $26 \%$ of the women had given birth. Nearly $45 \%$ of the households were headed by females; and the majority of heads of households were 35 years or older. The majority of heads of household were parents $(55 \%)$ followed by other relatives $(25 \%)$, unrelated persons $(15 \%)$ and only $9 \%$ of households were headed by young unmarried women. About 8 in 10 of the women were Christians; nearly 5 in 10 and about 4 in 10 had no/primary and secondary education respectively while only $11 \%$ had tertiary education. The proportion in rural residence was $53 \%$; and $75 \%$ were in the richer/richest wealth quintile group. Nearly $40 \%$ and $44 \%$ of the women had three or more and one lifetime sexual partners respectively. Almost 56\% have ever tested for HIV. Although knowledge of contraceptives was universal, only about $58 \%$ have ever used a contraceptive. 
Table I Socio-demographic profile of unmarried sexually experienced young women aged 15-24 years

\begin{tabular}{|c|c|c|c|c|}
\hline Socio-demographic variables & 2001 & 2006 & 2011 & Total \\
\hline \multicolumn{5}{|l|}{ Ever Given birth } \\
\hline No & $74.9(4 I I)$ & $72.0(458)$ & $74.7(552)$ & $73.9(\mid 42 I)$ \\
\hline Yes & $25.1(138)$ & $28.0(178)$ & $25.3(187)$ & $26.1(503)$ \\
\hline \multicolumn{5}{|l|}{ Age group } \\
\hline $15-19$ & $63.9(35 \mathrm{I})$ & $60.1(382)$ & $60.2(445)$ & $61.2(1178)$ \\
\hline $20-24$ & 36.1 (198) & $39.9(254)$ & $39.8(294)$ & $38.8(746)$ \\
\hline \multicolumn{5}{|l|}{ Age sexual debut } \\
\hline$<18$ & $78.7(432)$ & $73.0(463)$ & $71.0(525)$ & $73.9(\mid 42 I)$ \\
\hline $18+$ & $21.3(117)$ & $27.0(172)$ & $29.0(214)$ & $26.1(503)$ \\
\hline \multicolumn{5}{|l|}{ Age at birth } \\
\hline No births & $74.9(4 I I)$ & $72.0(458)$ & $74.7(532)$ & $73.9(1421)$ \\
\hline$<15$ & $0.9(5)$ & $0.8(5)$ & $1.2(9)$ & $1.0(19)$ \\
\hline $15-17$ & II.3 (62) & $10.8(69)$ & $9.6(7 I)$ & $10.5(202)$ \\
\hline $18+$ & $12.9(7 I)$ & $16.4(104)$ & $37.9(109)$ & $14.7(282)$ \\
\hline \multicolumn{5}{|l|}{ Age head of household } \\
\hline$<25$ & I7.I (94) & II.0 (70) & II.4 (84) & $12.9(248)$ \\
\hline $25-34$ & $16.9(93)$ & $11.9(76)$ & $12.0(89)$ & $13.4(258)$ \\
\hline $35+$ & $65.9(362)$ & $77.0(490)$ & $76.6(566)$ & $73.7(14 \mid 8)$ \\
\hline \multicolumn{5}{|l|}{ Sex of household } \\
\hline Male & $55.6(305)$ & $55.7(354)$ & $54.4(402)$ & $55.1(106 I)$ \\
\hline Female & $44.4(244)$ & $44.3(252)$ & $45.6(337)$ & $44.9(863)$ \\
\hline \multicolumn{5}{|l|}{ Head of household } \\
\hline Self & $12.4(68)$ & $6.9(44)$ & $7.6(56)$ & $8.7(168)$ \\
\hline Parent & $47.5(26 I)$ & $61.3(390)$ & $54.7(404)$ & $54.8(1055)$ \\
\hline Other relative & $26.4(145)$ & $21.2(135)$ & $26.0(192)$ & $24.5(472)$ \\
\hline Not related & $13.7(75)$ & $10.5(67)$ & II .8 (87) & $11.9(229)$ \\
\hline \multicolumn{5}{|l|}{ Religion } \\
\hline Christian & $79.2(435)$ & $85.2(542)$ & $83.5(617)$ & $82.8(1594)$ \\
\hline Muslim & $16.8(92)$ & I3.I (83) & $16.2(120)$ & $15.3(295)$ \\
\hline Other & $4.0(22)$ & $\mathrm{I} .7(\mathrm{II})$ & $0.3(2)$ & $1.8(35)$ \\
\hline
\end{tabular}


African Population Studies Vol. 29, No. 2, Supplement, 2015

Table I Continue

\begin{tabular}{lllll}
\hline Socio-demographic variables & 2001 & 2006 & Total
\end{tabular}

Educational attainment

None/Primary

48. I (264) $\quad 42.9(273) \quad 42.8(316) \quad 44.8(853)$

Secondary

$28.3(24 I)$

44.3 (282)

44.7 (330)

44.0 (853)

Tertiary

8.0 (44)

$12.7(8 \mathrm{I})$

$12.6(93)$

I I.3 (218)

Place of residence

Urban

$57.2(314) \quad 35.4(225) \quad 50.3(372) \quad 47.3(911)$

Rural

$42.8(235)$

$64.6(4 I I)$

$49.7(367)$

$52.7(1013)$

Wealth index group

Poorest/poor

$13.7(75)$

$9.1(58)$

8.5 (63)

$10.2(196)$

Middle

$26.8(147)$

10.5 (67)

$9.5(70)$

I4.8 (284)

Rich/Richer

$59.6(327)$

$80.3(511)$

$82.0(606)$

75. I (1444)

Number of lifetime sexual

partner

$$
\text { I }
$$

2

$\begin{array}{llll}0.0(00) & 59.9(381) & 64.4(476) & 44.5(857) \\ 0.0(00) & 23.9(152) & 20.8(154) & 15.9(306)\end{array}$

$3+$

$100.0(549)$

$16.2(103)$

I4.7 (109)

$39.6(761)$

HIV testing status

No

$84.5(464) \quad 66.0(420) \quad 27.2(201) \quad 56.4(1085)$

Yes

$15.5(85)$

$34.0(216)$

$72.8(535)$

$43.6(839)$

Knowledge of any modern FP

No

$$
1.6(9)
$$

I.7 (II)

$0.8(6)$

$1.4(26)$

Yes

98.I (540)

$98.3(625)$

$99.2(733)$

$98.6(1898)$

Ever used a modern contraceptives

\begin{tabular}{lcccc} 
No & $41.5(228)$ & $43.1(274)$ & - & $42.4(502)$ \\
Yes & $58.5(321)$ & $56.9(362)$ & - & $57.6(683)$ \\
\hline Total & $100.0(549)$ & $100.0(635)$ & $100.0(738)$ & $100.0(1924)$
\end{tabular}


Trends and correlates of premarital childbearing

Table 2 presents the differentials in the rate of young premarital motherhood. The table shows that young premarital motherhood increased from $25.1 \%$ in 200 I to $28 \%$ in 2006 and declined slightly to $25.3 \%$ in $20 \mathrm{I} \mathrm{I}$, which indicated that the rate of young premarital motherhood remained persistently high. Figure I also shows that there was no change in premarital childbearing over the period under study. Young motherhood was lower among women in the 15-19 years age group; higher among women who were $<18$ years at sexual debut; higher among women in households headed by females in all the surveys; and households headed by persons $<25$ years of age in the
2006 and the 2011 surveys and persons older than 34 years in all the three surveys. Women who headed their own households, followed by those in households headed by parents; and women with no/primary education, women in rural areas, in the richer/richest wealth index quintile in the 200 I survey and in the poorest/poorer wealth index quintile in the 2006 and the 201 I surveys also had higher rate of young motherhood. In addition, young motherhood increased with number of lifetime sexual partners in all the surveys. Young motherhood was also higher among women who reported knowledge of contraceptives and never used contraceptives in the $200 \mathrm{I}$ and the 2006 surveys.

Table 2 Socio-demographic patterns of premarital childbearing of young women aged $15-24$ years

\begin{tabular}{|c|c|c|c|c|c|c|}
\hline $\begin{array}{l}\text { Socio-demographic } \\
\text { variables }\end{array}$ & 2001 & $\chi^{2}$ & 2006 & $\chi^{2}$ & 2011 & $\chi^{2}$ \\
\hline \multicolumn{7}{|l|}{ Age group } \\
\hline $15-19$ & $16.8(35 \mathrm{I})$ & $35.8 * * * * *$ & $18.8(382)$ & $39.6 * * * *$ & $16.0(445)$ & $51.7 * * * *$ \\
\hline $20-24$ & $39.9(198)$ & & $4 I .7(254)$ & & $39.5(294)$ & \\
\hline \multicolumn{7}{|l|}{ Age sexual debut } \\
\hline$<18$ & $25.7(432)$ & 0.33 & $28.9(463)$ & 0.70 & $25.5(525)$ & 0.04 \\
\hline $18+$ & $23.1(117)$ & & $25.6(172)$ & & $24.8(2 \mid 4)$ & \\
\hline \multicolumn{7}{|c|}{ Age head of household } \\
\hline$<25$ & $22.3(94)$ & 0.73 & $35.7(70)$ & $6.6^{*}$ & $33.3(84)$ & 4.1 \\
\hline $25-34$ & $23.7(93)$ & & I7.I (76) & & $20.2(89)$ & \\
\hline $35+$ & $26.2(362)$ & & $28.6(490)$ & & $24.9(566)$ & \\
\hline \multicolumn{7}{|l|}{ Sex of household } \\
\hline Male & $18.7(305)$ & 15.2***** & $22.3(354)$ & $12.7 * * * *$ & $20.6(402)$ & $10.1 * * *$ \\
\hline Female & $33.2(244)$ & & $35.1(252)$ & & $30.9(337)$ & \\
\hline \multicolumn{7}{|l|}{ Head of household } \\
\hline Self & $26.5(68)$ & $7.1^{*}$ & $40.9(44)$ & 4.1 & $4 I . I(56)$ & $11.8 * * * *$ \\
\hline Parent & $29.5(26 I)$ & & $27.2(390)$ & & $26.7(404)$ & \\
\hline Other relative & $17.9(\mid 45)$ & & $25.9(135)$ & & $20.3(192)$ & \\
\hline Not related & $22.7(75)$ & & $28.4(67)$ & & $19.5(87)$ & \\
\hline \multicolumn{7}{|l|}{ Religion } \\
\hline Christian & $26.0(435)$ & 0.8 & $27.1(542)$ & 2.3 & $25.3(617)$ & 0.7 \\
\hline Muslim & $21.7(92)$ & & $31.3(83)$ & & $25.0(120)$ & \\
\hline Other & $22.7(22)$ & & $45.5(11)$ & & $50.0(2)$ & \\
\hline
\end{tabular}


African Population Studies Vol. 29, No. 2, Supplement, 2015

\begin{tabular}{|c|c|c|c|c|c|c|}
\hline $\begin{array}{l}\text { Socio-demographic } \\
\text { variables }\end{array}$ & 2001 & $\chi^{2}$ & 2006 & $\chi^{2}$ & 2011 & $\chi^{2}$ \\
\hline \multicolumn{7}{|c|}{ Educational attainment } \\
\hline None/Primary & $3 I . I(264)$ & $9.8 * * *$ & $32.2(273)$ & $8.2^{* *}$ & $29.4(316)$ & $16.7^{* * * * *}$ \\
\hline Secondary & $20.3(24 I)$ & & $27.3(282)$ & & $26.1(330)$ & \\
\hline Tertiary & $15.9(44)$ & & $16.0(8 \mathrm{I})$ & & $8.6(93)$ & \\
\hline \multicolumn{7}{|l|}{ Place of residence } \\
\hline Urban & $22.3(3 \mid 4)$ & $3.1^{*}$ & $23.1(225)$ & $4.1^{*}$ & $22.6(372)$ & $2.9 *$ \\
\hline Rural & $28.9(235)$ & & $30.7(4 I I)$ & & $28.1(367)$ & \\
\hline \multicolumn{7}{|l|}{ Wealth index group } \\
\hline Poorest/poor & $22.7(75)$ & 04 & $48.3(58)$ & 14.6 **** & $33.3(63)$ & $6.3 *$ \\
\hline Middle & $24.5(147)$ & & $19.4(67)$ & & $34.3(70)$ & \\
\hline Rich/Richer & $26.0(327)$ & & $26.8(5 I I)$ & & $23.4(606)$ & \\
\hline \multicolumn{7}{|l|}{$\begin{array}{l}\text { Number of lifetime } \\
\text { sexual partner }\end{array}$} \\
\hline I & $0.0(00)$ & & I $9.7(38 \mathrm{I})$ & $36.9 * * * *$ & $20.2(476)$ & $29.2 * * * *$ \\
\hline \multicolumn{7}{|c|}{$35[$ ᄃ } \\
\hline $3+$ & $25.1(549)$ & & $47.6(103)$ & & $45.0(109)$ & \\
\hline \multicolumn{7}{|l|}{ HIV testing status } \\
\hline No & $26.1(464)$ & 1.4 & $24.0(420)$ & $9.5 * * *$ & $9.5(201)$ & $36.7 * * * *$ \\
\hline Yes & $20.0(85)$ & & $35.6(216)$ & & $31.2(535)$ & \\
\hline \multicolumn{7}{|c|}{ Knowledge of modern } \\
\hline \multicolumn{7}{|c|}{ FP } \\
\hline No & $24.8(540)$ & & $27.5(625)$ & & $25.1(733)$ & \\
\hline \multicolumn{7}{|l|}{ Yes } \\
\hline \multicolumn{7}{|l|}{$\begin{array}{l}\text { Ever used } \\
\text { contraceptives }\end{array}$} \\
\hline & $23.2(228)$ & 0.7 & $29.6(274)$ & 0.6 & - & - \\
\hline No & $26.5(32 I)$ & & $26.8(362)$ & & - & - \\
\hline \multicolumn{7}{|l|}{ Yes } \\
\hline Total & 25.1 (549) & & $28.0(635)$ & & $25.3(738)$ & \\
\hline
\end{tabular}


Figure 1 Trends in rate of premarital childbearing by

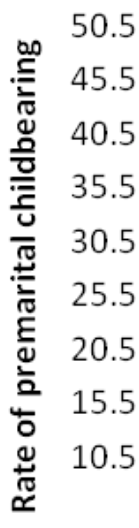

women aged $14-24$ years in Uganda

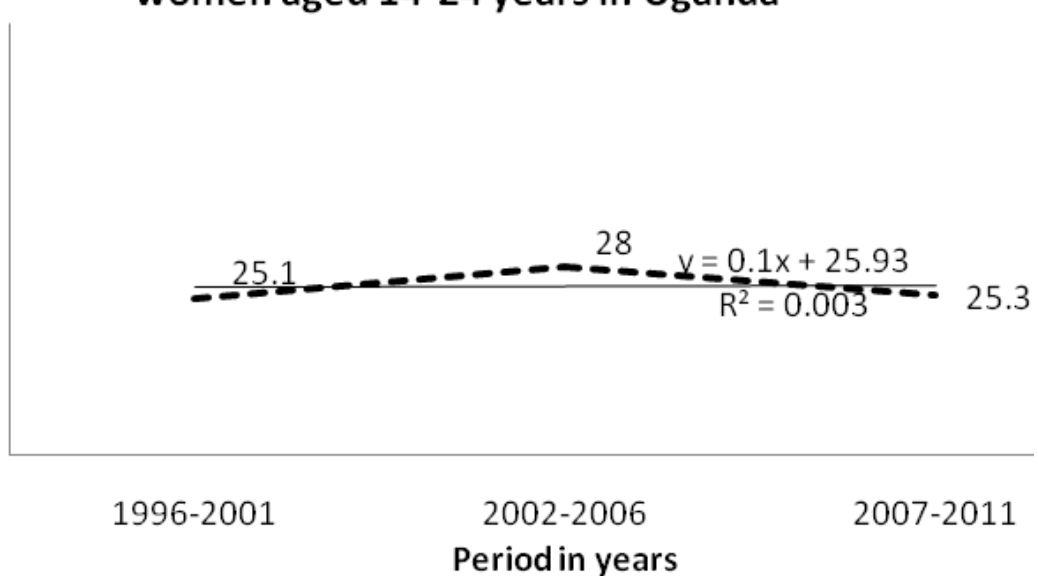

Predictors of premarital childbearing

The adjusted logistic regression model results in Table 3 shows that young premarital motherhood was significantly more likely if the women were in the 20 24 year age group $(O R=8.28, p<0.000 \mathrm{I})$ in 200I, $(O R=5.82, p<0.000 \mathrm{I})$ in 2006 and $(O R=6.76, p<0.000 \mathrm{I})$ in $20 \mathrm{II}$. It is also more likely to occur if the women had sexual debut at $<18$ years $(O R=2.66$, $\mathrm{p}<0.00 \mathrm{I})$ in 200I, $(\mathrm{OR}=2.47, \mathrm{p}<0.00 \mathrm{I})$ in 2006 and $(O R=1.93, p<0.01)$ in $201 \mathrm{I}$; and higher in female headed households in $200 \mathrm{I}(\mathrm{OR}=2.17, \mathrm{p}<0.00 \mathrm{I})$, in 2006 $(\mathrm{OR}=1.89, \quad \mathrm{p}<0.00 \mathrm{I})$ and in $20 \mathrm{II}$ $(\mathrm{OR}=1.58, \mathrm{p}<0.05)$. Table 3 also revealed that the likelihood of young premarital motherhood in Uganda decreased with the level of education by $7.04(p<0.000$ I) and $2.94(\mathrm{p}<0.05)$ at no/primary and secondary education in $200 \mathrm{I}, 5.82$ $(\mathrm{p}<0.0000 \mathrm{I})$ and $3.23 \quad(\mathrm{p}<0.00 \mathrm{I})$ at no/primary and secondary education in 2006 and $10.85 \quad(p<0.000 \mathrm{I})$ and 8.15 $(p<0.000 \mathrm{I})$ at no/primary and secondary education in 201 I. Data from 2006 and 201 I shows that women with more than one lifetime sex partners, resident in rural areas in 2006, ever tested for HIV in 2006 and $20 \mathrm{II}$ and never used contraceptives in 200 I were significantly more lilely than women with one sex partner, resident in urban areas, never tested for HIV and never used contraceptives to have experienced young premarital motherhood. 
African Population Studies Vol. 29, No. 2, Supplement, 2015

Table 3Adjusted logistic regression Odds Ratios showing trends in predictors of premarital childbearing among young women aged 15-24 years in Uganda

\begin{tabular}{|c|c|c|c|c|c|c|}
\hline \multirow[t]{2}{*}{ Selected covariates } & \multicolumn{2}{|c|}{2001} & \multicolumn{2}{|c|}{2006} & \multicolumn{2}{|c|}{2011} \\
\hline & OR & $\mathrm{Cl}$ & OR & $\mathrm{Cl}$ & OR & $\mathrm{Cl}$ \\
\hline \multicolumn{7}{|l|}{ Age group } \\
\hline $15-19(\mathrm{R})$ & 1.00 & & 1.00 & & 1.00 & \\
\hline $20-24$ & $8.28 * * * *$ & $4.73-14-5$ & $5.82 * * * *$ & $3.4 \mid-9.93$ & $6.76 * * * *$ & $4.04-|| .3 \mid$ \\
\hline \multicolumn{7}{|l|}{ Age at first sex } \\
\hline$<18$ & 2.66 **** & $1.43-4.97$ & $2.47^{* * * *}$ & $1.4 \mid-4.32$ & $1.93 * *$ & I.14-3.28 \\
\hline $18+(R)$ & 1.00 & & 1.00 & & 1.00 & \\
\hline \multicolumn{7}{|l|}{$\begin{array}{l}\text { Age of household } \\
\text { head }\end{array}$} \\
\hline$<25(\mathrm{R})$ & 1.00 & & 1.00 & & 1.00 & \\
\hline $25-34$ & 1.64 & $0.50-5.39$ & 0.49 & $0.15-1.60$ & $\mathrm{I} .46$ & $0.42-5.03$ \\
\hline $35+$ & 1.26 & $0.37-4.25$ & 1.12 & $0.37-3.40$ & 1.00 & $0.30-3.25$ \\
\hline \multicolumn{7}{|l|}{$\begin{array}{l}\text { Sex of household } \\
\text { head }\end{array}$} \\
\hline Male (R) & 1.00 & & 1.00 & & 1.00 & \\
\hline Female & $2.17^{* * * *}$ & I.35-3.47 & $1.89 * * *$ & $1.23-2.92$ & $1.58^{*}$ & I.04-2.42 \\
\hline \multicolumn{7}{|l|}{ Head of household } \\
\hline \multicolumn{7}{|l|}{ Self } \\
\hline Parent & 0.86 & $0.22-3.30$ & 0.97 & $0.25-3.75$ & 2.26 & $0.54-9.46$ \\
\hline Other relative & 1.74 & $0.80-3.78$ & 0.58 & $0.28-I .20$ & 1.61 & $0.79-3.28$ \\
\hline \multirow[t]{2}{*}{ Unrelated (R) } & 0.80 & $0.36-1.73$ & 0.89 & $0.42-1.91$ & 1.33 & $0.64-2.78$ \\
\hline & 1.00 & & 1.00 & & 1.00 & \\
\hline \multicolumn{7}{|l|}{ Religion } \\
\hline Christian (R) & 1.00 & & 1.00 & & 1.00 & \\
\hline Muslim & 0.73 & $0.39-1.37$ & 1.08 & $0.59-1.97$ & 1.31 & $0.76-2.26$ \\
\hline Other & 0.68 & $0.20-2.26$ & 1.67 & $0.37-7.56$ & 3.17 & $0.02-46.32$ \\
\hline \multicolumn{7}{|l|}{ Level of education } \\
\hline No/primary & $7.04 * * * *$ & $2.59-$ & $5.82 * * * *$ & $2.50-13.58$ & $10.85 * * * *$ & $7.56-31.98$ \\
\hline Secondary & $2.94^{*}$ & 19.12 & $3.23 * * *$ & $1.50-6.94$ & $8.15^{* * * * *}$ & $3.48-19.09$ \\
\hline Tertiary (R) & 1.00 & I.14-7.59 & 1.00 & & 1.00 & \\
\hline
\end{tabular}


African Population Studies Vol. 29, No. 2, Supplement, 2015

\section{Table 3 Continue}

\begin{tabular}{|c|c|c|c|c|c|c|}
\hline \multirow[t]{2}{*}{ Selected covariates } & 2001 & 2006 & 2011 & 2001 & 2006 & 2011 \\
\hline & OR & $\mathrm{Cl}$ & OR & OR & $\mathrm{Cl}$ & OR \\
\hline \multicolumn{7}{|l|}{ Wealth index group } \\
\hline Poorest/poor & 0.77 & $0.39-1.53$ & $2.47^{* * *}$ & I.22-4.99 & I.38* & $0.68-1.77$ \\
\hline Middle & 0.88 & $0.5|-| .5 \mid$ & 0.65 & $0.31-1.37$ & 1.35 & $0.72-2.53$ \\
\hline Rich/richest (R) & 1.00 & & 1.00 & & 1.00 & \\
\hline \multicolumn{7}{|l|}{ Total number of } \\
\hline \multicolumn{7}{|l|}{ lifetime sex partners } \\
\hline I & - & - & 1.00 & & 1.00 & \\
\hline 2 & - & - & $2.13^{* * * *}$ & $1.28-3.52$ & 1.09 & $0.66-1.80$ \\
\hline $3+$ & - & - & $3.42 * * * *$ & $1.95-5.99$ & $2.32 * * * *$ & I.33-4.07 \\
\hline \multicolumn{7}{|l|}{ Place of residence } \\
\hline Urban (R) & 1.00 & & 1.00 & & 1.00 & \\
\hline Rural & 1.191 & $0.7 \mid-2.0 I$ & $2.24 * * *$ & $1.32-3.8 \mid$ & $1.39 * *$ & $0.87-2.02$ \\
\hline \multicolumn{7}{|l|}{ HIV testing status } \\
\hline Ever tested & 0.72 & $0.36-1.42$ & $1.85^{* * *}$ & $1.17-2.92$ & $4.93 * * * *$ & $2.79-8.69$ \\
\hline Never tested(R) & 1.00 & & 1.00 & & 1.00 & \\
\hline \multicolumn{7}{|c|}{ Knowledge of Modern } \\
\hline \multicolumn{7}{|l|}{ contraceptives } \\
\hline \multicolumn{7}{|l|}{ Yes (R) } \\
\hline \multirow[t]{2}{*}{ No } & 1.00 & & 1.00 & & 1.00 & \\
\hline & 0.43 & $0.09-2.03$ & 0.55 & $0.12-2.43$ & 0.49 & $0.07-3.19$ \\
\hline \multicolumn{7}{|l|}{ Use of modern } \\
\hline \multicolumn{7}{|l|}{ contraception } \\
\hline Ever used (R) & 1.00 & & 1.00 & & - & \\
\hline Never used & $1.63^{*}$ & $1.00-2.67$ & 0.77 & $0.48-I .23$ & - & - \\
\hline
\end{tabular}

\section{Discussion}

Young premarital motherhood is associated with adverse pregnancy, health and social outcomes (Christofieds et al., 20I4; Najati \& Gojazadeh, 20I0) including HIV infection which occurs more frequently among young unmarried sexually active adults than any other population group in large HIV epidemics (UNICEF, 20II). The prevalence of premarital childbearing among young women in Uganda is $25.1 \%, 28 \%$ and $25.3 \%$ in 2001,2006 and 2011 
respectively, which indicates that the country has one of the highest young motherhood rates in sub-Saharan Africa.

The prevalence of young motherhood increased by $12 \%$ between the $200 \mathrm{I}$ and the 2006 surveys, but declined by only $10 \%$ between the 2006 and the 2011 surveys. A trend line fitted to track changes in premarital births revealed no overall decline in the prevalence of young premarital motherhood over the period under study. The result indicated that the hypothesis that "young motherhood increased with the number of lifetime sexual partners" was also confirmed. Among the control variables, the predictors of young premarital motherhood increased among women in the 20-24 year age group, living in female headed households and had no/primary education followed by women in with secondary education in all the surveys.

The study found that women who had sexual debut at $<18$ years were significantly more likely to have been young mothers in all the three surveys. This finding is consistent with results of a previous study (Glynn, Kayine, Floyd, Banda, Francis-Chizoro, Tanton, Molesworth et al., 2010) which associated sexual debut at a young age with unprotected sex, multiple partners and at risk of becoming young mothers. The current study also found that the mean number of lifetime sexual partners of the study population was two and nearly 6 in 10 women had two or more lifetime sexual partners, which is also attributed to the young age at sexual debut estimated at 16 years. This finding is consistent with previous studies, (Meekers, 1994; Forrest. 1994) which found that women who are young at sexual debut have premarital sex for a longtime with many partners concurrently or having a high partner turnover rate which also increased the risk of unintended fertility. The finding reinforces concerns about contraceptive services in Uganda where stock outs are endemic and access to services is poor and methods choice are limited especially in rural areas (Kabagenyi, Jennings, Reid, Nalwadda, Ntozi \& Atuyambe, 20l4) where premarital childbearing was also found to be common. Even where contraceptives are available, its use by young women is impeded by myths and misinformation about the long term side effects of contraceptives leading to the high prevalence of young premarital fertility.

Age is an important predictor of fertility and by 24 years of age, 4 in 5 women in Uganda have given birth, suggesting that fertility at the 20-24 year age group is not surprising and would have not been a concern if the women were in union which sanctions sexual activity and legitimizes fertility. A previous study found that most young unmarried adults do not want to become pregnant (Forrest, 1994) indicating that fertility among nonunionized women aged $20-24$ is due to non-use of contraceptives including the condom. In a previous study, Wong (20l2) also attributed fertility in this group of women to loss of parental authority, peer pressure and the use of sex in exchange for gifts and money, especially in households headed by females and more specifically those headed by young women. Contraceptive failure which is common among young women could also account for the high fertility rate of these women (Blanc, Tsui, Croft \& Trevitt, 2009). 
The higher risk of young motherhood in rural areas indicates that fertility norms in rural communities are changing due to the introduction of new norms or family structures and lifestyles including the single mother headed households and prostitution. A similar rural-urban differential was observed in previous studies (Bbaale \& Mpuga, 20l I; Oyefara, 2005) which ascribed young age at sexual debut and limited access to contraceptives in rural areas as some of the reasons for premarital childbearing by young women. Furthermore, the finding that female headed households were also at increased risk of young motherhood is consistent with a previous study which attributed premarital birth among young mothers to poverty (Winters \& Winters 20I2). A previous study also found that poverty encourages the use of sex as a survival strategy which could have led to unintended childbearing by young unmarried women (Singh et al., 2005). The perception by young women of sexually active single mothers that premarital sex is an acceptable sexual behavior could have also contributed to the high prevalence of premarital childbearing (Witbeck, Simons \& Kao 1994). The higher likelihood of premarital childbearing among young unmarried women with no/primary education is consistent with results of a previous study (Bbaale \& Mpuga, 20II) which attributed the findings to the incompatibility of education with childbearing and the role of education in increasing knowledge, changing attitudes and adoption of behaviour that delay fertility among women with secondary and tertiary education. Conversely, the finding was inconsistent with another study
(Garenne \& Zwang, 2004) which found that higher education was associated with increased risk of young motherhood due to the combined effect of delayed age at marriage and the long duration of nonmarital sexual activity.

\section{Limitations of the study}

Although the study identified some significant predictors of young motherhood, the results and conclusions could have been biased by a number of aspects. Firstly, social desirability biases associated with under reporting of premarital fertility which is culturally discouraged. Secondly, sample variations between the surveys could affect the comparison of rates of young motherhood. Thirdly, the cross-sectional nature of the data could have affected results due to censoring of women who become pregnant soon after the surveys. Lastly, the estimation of young premarital motherhood as a point indicator could misclassify the event for variables on which data were collected at the time of interview, putting the temporality of the event for transient variables in question. This might explain why women who have ever tested for HIV were more likely to have had a premarital birth, yet HIV testing is a requirement during pregnancy to which non pregnant women are usually exempted.

\section{Conclusion}

This study concludes that the prevalence of premarital childbearing among young sexually active women in Uganda remained high over the 15 year period under study. The significantly higher risk of premarital 
childbearing in this group of women is attributed to multiple lifetime sexual partnerships mostly in the 20-24 year age cohort; young women in female headed households and women in rural areas. This sexual and reproductive behavior is a major risk for the sexual and reproductive health and socioeconomic wellbeing of women in Uganda. In this regard policies and programmes aimed at improving the reproductive health and socioeconomic wellbeing of young women needs to be strengthened. The programmes should include strategies that provide effective information about healthy sexual life; counseling on the risks of unprotected sexual activity and multiple lifetime sexual partnerships; change traditional gender attitudes and perceptions about young women; and provide access to quality education and productive resources for young women. These strategies will contribute to reducing the incidence of unintended pregnancies and enhance empowerment of young women and female headed households with the aim of preventing the use of sex as a survival strategy.

\section{Acknowledgements}

The author appreciates UBOS for permission to access the UDHS data set from the MEASURE DHS website. Thanks also to the reviewers for the constructive contributions they have made to the manuscript.

\section{References}

Aderibigbe, A.A., Araoye, M.O., Akande, T.M., Musa, O.I.,Monehin, J.O. \&
Babatunde, O.A. 20II.Teenage pregnancy and prevalence of abortion among In-school adolescents in North Central Nigeria. Asian Social Sciences, $7(1): 122-127$.

Bbaale, E.\&Mpuga, P. (20II). Female Education, Contraceptive Use, and Fertility: Evidence from Uganda Consilience. The Journal of Sustainable Development, 6(I): 20-47.

Behrman, J.R., Murphy, A., Quisumbing, A.R.\&Yount, K. 20I0. Mothers' human capital and the intergenerational transmission of poverty. CPRC Working Paper 160, February 2010.

Blanc, A.K., Tsui, A.O., Croft, T.N.\&Trevitt, J.L. 2009.Pattern and trends in adolescents' contraceptive use and discontinuation in developing countries and comparisons with adult women. International Perspective Sexual Reproductive Health, 35(2):637I.

Bogale, A.\&Seme, A. 2014.Premarital sexual practices and its predictors among in- school youths of shendi town, west Gojjam zone, North Western Ethiopia.Reproductive Health, I I:49.

Chirowa, F., Atwood, S. \& Van der Putten, M. 2013. Gender inequality, health expenditureandmarernal mortality in sub-Saharan Africa: A secondary data analysis. African Journal Primary Health Care Family Medicine, 5(I), Art. \#47/ http://dx.doi.org//0.4102/phcfm. v5il.47l.http://www.phcfm.org/index.p $\mathrm{hp} / \mathrm{phcfm} /$ article/view/47//7/3

Christofides, N.J., Jewkes, R.K., Dundle, K.I., Nduna, M., Shai, N.J. \&Sterl, C. 2014.Early adolescent pregnancy increases risk of incident HIV infection 
in the Eastern Cape, South Africa: a longitudinal study. Journal of the International AIDS Society, I7: 18585. doi.org/I0.7448/IAS. I7.I.18585.

Elisa, T.L.\& Wang, J. 1992. Statistical methods for survival data analyses. 2nd ed. NewYork, NY: John Willy \& Sons, Inc.

Ellis, B.J., Bates, J.E., Dodge, K.A., Fergusson, D.M., Horwood, L.J., Pettit, G.S \&Woodward, L. 2003. Does Father Absence Place Daughters at Special Risk for Early

emotional well-being of the next generation. The Future of Children 15, (2):75-96.

Forrest, J.D. 1994. Epidemiology of unintended pregnancy and contraceptive use.America Journal of Obstetrics and Gynarecology, |70: | 485-| 489.

Garenne, M. \&Zwang, J. 2004.Social change and premarital fertility in Madagascar. Southern African Journal of Demography, 9(I):27-48.

Glynn, J.R., Kayine, N., Floyd, S., Banda, E., Francis-Chizororo, M., Tanton, C., Molesworth, A., Hemmings, J., Crampin, A.C.\& French, N. 2010.Age at menarche, schooling, and sexual debut in northern Malawi. PLoS one 2010;5:el5334.http://journals.plos.org/ plosone/article?id $=10.137 \mid$ /journal.po ne.00I5334

Gupta, N.\&Mahy, M. 2005. Sexual initiation among adolescent girls and boys: trends and differentials in SubSaharan Africa. Archives of Sexual Behaviour, 32(I):4I-53.

Högnäs, R.A \& Carlson, M.J. 20I2. Like Parent, Like Child?: The Intergenerational Transmission of
Nonmarital Childbearing. Social Science Research 4I, (6): |480-|494. doi:10.1016/j.ssresearch.2012.05.0I2. Kabagenyi, A., Jennings, L., Reid, A., Nalwadda, G., Ntozi, J. \&Atuyambe, L. 20I4.Barriers to male involvement in contraceptive uptake and reproductive health servies: A qualitative study of men and women's perceptions in two rural districts in Uganda. Reproductive Health, I I:2 I.doi: I0. I I86/ I 742-4755I I-2I.http://www.reproductivehealth-journal.com/content/I I/I/2 I

Kalichman, S.C., Ntseane, D., Ntomang, K., Segwabe, M., Phorano, O. \&Simbayi, L.C. 2007. Recent multiple sexual partners and HIV transmission risks among people living with HIV/AIDS in Botsana. Sexual Transmitted Infections, 83:37|-375. doi:

10. I |36/sti.2006.023630.http://sti.bmj. com/content $/ 83 / 5 / 37$ I full

Karabo, M \& Ayiga, N. 2014.Rates and predictors of school pregnancy among black women in the North West province. African Population Studies 28(I):636-647.

Kennedy, E., Gray, N., Azzopardi, P.\&Creati, M. 20I I. Adolescent fertility and family planning in Eash Asia and the Pacific: $R$ review of DHS reports. Reproductive Health, 8:II http://www.reproductive-healthjournal.com/content/8/I/I I.

Langeni, T.T. 2005.Gender power imbalance on women's capacity to negotiate self-protection against HIV/AIDS in Botswana and South Africa. Africa Health Sciences 5(3): 188-197. 
Madhavan, S.\& Thomas, K. 2005. Early childbearing and schooling: New evidence from South Africa. Comparative Education Review, 49(4):452-467.

Marston, M., Beguy, D., Kabiru, C.\& Cleland, J. 2013.Predictors of sexual debut among young adolescents in Nairobi's informal settlements. International Perspectives on Sexual and Reproductive Health, 39(I):2231.doi: I0.1363/39022/3.

Mayer-Foulkes, D. 2009.Economic geography of human development: Stratified growth in Bolivia, Brazil, Guatemala and Peru. Research for Public Policy Human Development.HD-06-New York: RBLAC-UNDP.

Meekers, D. 1994. Sexual Initiation and Premarital Childbearing in Sub-Saharan Africa, Population Studies 48, (I): 4764, DOI:

I0.1080/003247203 | 000 | 47466 .

Najati, N.\&Gojazadeh, M. 20I0. Maternal and neonatal complications in mothers aged under 18 years. Patient Preference and Adherence, 4: 219222.

Oyefara, J.L. 2005.Age at First Marriage and Fertility Transition in South Western Nigeria.UNILAG. Sociological Review, 6:83-105.

Raj, A., Saggurti, N., Balaiah, D \& Silverman, J.G. 2009. Prevalence of child marriage and its effect on fertility and fertility-control outcomes of young women in India: a cross-sectional, observational study. Lancet, 373(9678): |883-|889.

Richter, L., Chikovore, J \& Makusha, T. 2010.The status of fatherhood and fathering in South Africa.Child Education $\quad 86, \quad$ (6): 360-365. doi: I0.1080/00094056.2010.10523। 70 Samandari, G.\&Speizer, I.S. 2010. Adolescent sexual behavior and reproductive outcomes in Central America: Trends over the past two decades. International Perspective Sexual Reproductive Health, 36(I):979-98I. doi:I0.2 I05/AJPH.20I0.300092.

Singh, S., Prada, P., Mirembe, F.\&Kiggundu, C. 2005. The incidence of induced abortion in Uganda. International Family Planning Perspectives, 31 (4): |83-19|.

Sommer, M. 20I I. An overlooked priority: Puberty in sub-Saharan Africa. American Journal of Public Health, I0I(6):979-98I. doi I0.2। 05/AJPH.2010.300092.

Steele, F., Sigle-Rushton, W \&Kravdal, $\varnothing$. 2009. Consequences of Family Disruption on Children's Educational Outcomes in Norway.Demography 46(3):553-74.

UAC. 20I4. HIV AND AIDS Uganda country progress report, 2013. Kampala, Uganda AIDS Commission.

UBOS \& ICFI. 20I 2. Uganda Demographic and Health Survey 20II. Kampala, Uganda: Uganda Bureau of Statistics and Calverton, Maryland: ICF International Inc.

UNFPA. 2010. How universal is access to reproductive health: Review of evidence. New York: United Nations Populations Fund.

Van Lith, L.M., Yahner, M.\&Bakamjian, L. 2013. Women's growing desire to limit births in sub-Saharan Africa: meeting 
the challenge. Global Health: Science and Research, I(I):97-107.

Wambade, F. 2014. Mbale youth ignorant about condom use. Kampala. Uganda: Daily Monitor Publication Wednesday, 16 July.

Wegner, L., Flisher, A.J., Caldwell, L.L., Verganani, T.\& Smith, E.A. 2008. Health wise South Africa: cultural adaptation of a school based risk prevention programme. Health Education Research, 23(6): I085-1096.

Winters, L.I \& Winters, P.C. 20I2. Black Teenage Pregnancy: A Dynamic Social Problem. SAGE Open, 2: I-I4.
Witbeck, L.B., Simons, R.L. \& Kao, M.Y. 1994. The Effects of divorced mother's dating behaviors and sexual attitudes on the sexual attitudes and behaviours of their adolescent children. Journal of Marriage and Family, 56(3): 615-621.

Wong, L.P. 20I2.Qualitative Inquiry into Premarital SexualBehaviours and Contraceptive Use among Multiethnic Young Women: Implications for Educations and Future Research. PLoS ONE, $\quad 7(12)$ : e5I 745 . doi: 10.137|/journal.pone.005 I745.http ://journals.plos.org/plosone/article?id= | 0.137|/journal.pone.005 | 745 